\title{
Pioneer vegetation on glacier forelands in southern Norway: emerging communities?
}

\author{
Robbins, Jane A. ${ }^{1 *}$ \& Matthews, John A. ${ }^{2}$ \\ ${ }^{1}$ School of Animal, Rural and Environmental Sciences, Nottingham Trent University, Brackenhurst, Southwell, \\ Nottingham NG24 OQF, UK; \\ ${ }^{2}$ Geography Department, School of the Environment and Society, Swansea University, Singleton Park, Swansea SA2 \\ 8PP, UK; Email J.A.Matthews@swansea.ac.uk; \\ Corresponding author; E-mail jane.robbins@ntu.ac.uk
}

\begin{abstract}
Question: How variable is the pioneer plant community on glacier forelands in southern Norway, both in terms of species composition and geographical distribution?
\end{abstract}

Location: The Jotunheim and Jostedalsbreen regions of southern Norway $\left(61^{\circ}-62^{\circ} \mathrm{N}, 6^{\circ}-9^{\circ} \mathrm{E}\right)$.

Methods: The relative frequencies of vascular plant species were recorded in the pioneer zones of 43 glacier forelands, with an altitudinal range of $80-1860 \mathrm{~m}$ (boreal to high alpine) and an east-west range of $100 \mathrm{~km}$. Classification and ordination techniques were used to search for evidence of consistently recurring communities, variability along a continuum or stochasticity.

Results: Mean variability in species composition between all glacier forelands sampled was 65\% (Sørensen dissimilarity). Poa alpina, Oxyria digyna, Deschampsia alpina and Festuca ovina had the highest frequency, occurring on over $80 \%$ of forelands. Non-metric multidimensional scaling did not reveal clear divisions between groups of sites, but cluster analysis, multi-response permutation procedures and indicator species analysis suggested two sub-communities: the Saxifraga cespitosa-Trisetum spicatum sub-community is restricted to forelands above $1100 \mathrm{~m}$ in the Jotunheim region; whereas the D. alpina$O$. digyna sub-community has a wider altitudinal range of $80-1780 \mathrm{~m}$. Variance partitioning indicated that altitude alone accounts for $24 \%$, distance east for $18 \%$, and the component shared by altitude and distance east for $17 \%$ of the variance in species composition.

Conclusions: At the broadest scale, pioneer vegetation on the glacier forelands can be viewed as a single $P$. alpina$O$. digyna community of predominantly wind- and waterdispersed perennials. However, this community shows a high degree of variability, with dominant species missing from a number of sites, and is poorly structured, suggesting a degree of stochasticity. Furthermore, the pioneer vegetation can be dissected within a continuum of variation to produce two emerging sub-communities, reflecting the influence of environmental factors and, possibly, early successional development within the pioneer zone. Variance partitioning indicates that altitudinal and continentality gradients are important in accounting for a significant proportion of the variability within this dataset.

Keywords: Arctic-alpine vegetation; Cluster analysis; Disturbed habitats; Glacier forelands; Indicator species analysis; Multi-response permutation; Non-metric multidimensional scaling; Pioneer community; Primary succession; Variance partitioning.

Nomenclature: Lid \& Lid (1994).

\section{Introduction}

Glacier retreat during the 20 th century has been a response to both relatively high summer temperatures and relatively low winter precipitation (Nesje 1989; Winkler 1996) and it is predicted that up to $98 \%$ of Norwegian glaciers may disappear by 2100 (Nesje et al. 2008). Land uncovered by glacial retreat provides an opportunity to study the earliest stage of primary succession, in which pioneer plant colonisation occurs. Understanding this initial phase of vegetation establishment is a vital component of successional theory, has practical application for land reclamation and habitat restoration and, in light of predicted climate change, it is important that the species composition of glacier foreland pioneer zones is recorded. Studies of vegetation succession on recently deglaciated terrain were reviewed by Matthews (1992, 1999), and recent studies of plant colonisation on glacier forelands include Jones \& del Moral (2005), Haugland \& Beatty (2005), Raffl et al. (2006), Moreau et al. (2008), Cutler et al. (2008) and Mori et al. (2008). A wider analysis of the primary succession literature is provided by Walker \& del 
Moral (2003). Theoretical understanding of succession is critically reviewed by McCook (1994) and Pickett \& Cadenasso (2005). Of particular relevance to early successional species composition are considerations of adaptive strategies (dispersal, colonisation and growth rates), tolerance to stress and disturbance, and the availability of safe sites. However, analysis of the pioneer zone of a large number of glacier forelands in a single research project has not previously been conducted.

Examples of research into variability of the pioneer stage of succession includes the work of Spence (1989), Elven (1978) and Persson (1964) on glacier forelands, and del Moral et al. (2005) on mudflows and pumice surfaces on Mount St. Helens, all of which identified haphazard, random or stochastic pioneer assemblages. In contrast to these findings, Matthews (1978a), Haugland \& Beatty (2005) and Caccianiga et al. (2001) identified consistent groups of species within the pioneer stage on glacier forelands.

In this study, the frequency of occurrence of pioneer vascular plant species on glacier forelands was analysed to provide evidence of the extent to which species composition reflects consistently recurring communities, forms a continuum of variability and/or exhibits stochasticity. For the purposes of this study, Austin's (2005) definition of a plant community is considered appropriate, i.e. a consistent floristic composition, uniform physiognomy, occurring in a particular environment and occurring at several locations. Theories explaining observed patterns of variability in space and time within established vegetation have a long history of controversy and debate (e.g. Clements 1916, 1936; Gleason 1917, 1927; Whittaker 1951, 1967; Collins et al. 1993; Austin 1999; Oksanen \& Minchin 2002; Lortie et al. 2004). However, the disturbed sites typical of the pioneer stage of succession have largely been excluded from this debate (Daubenmire 1966) and are a significant omission (Cottam 1966), particularly in light of the fact that substrate stability is unusual in arctic-alpine vegetation. If stochastic factors have a strong influence on pioneer vegetation, the data would be expected to show a high level of variability and unexplained variance.

\section{Material and Methods}

\section{Study area}

The study area (Fig. 1) includes the Jotunheim and Jostedalsbreen regions of southern Norway, which lie between latitudes $61^{\circ}$ and $62^{\circ} \mathrm{N}$ and long- itudes $6^{\circ}$ and $9^{\circ} \mathrm{E}$. The glacier forelands studied have an altitudinal range of $80-1860 \mathrm{~m}$ a.s.l. The Jotunheim region is situated across the transition between the maritime west and the more continental east, includes the highest mountain range in northern Europe and lies mainly above the treeline, which occurs at $1000-1200 \mathrm{~m}$. The mean annual air temperature is $-3.1^{\circ} \mathrm{C}$, with a July mean of $+5.7^{\circ} \mathrm{C}$ and a January mean of $-10.7^{\circ} \mathrm{C}$, and the mean annual precipitation is $860 \mathrm{~mm}$ at an altitude of $1413 \mathrm{~m}$ (Sognefjell meteorological station) (Aune 1993; Førland 1993). There are approximately 300 glaciers and small ice caps within the Jotunheim mountains, and the lower limit of discontinuous permafrost lies at about $1490 \mathrm{~m}$ (Isaksen et al. 2002). An area of $1151 \mathrm{~km}^{2}$ is protected under National Park status and the main land uses are outdoor recreation and summer grazing of sheep, goats, cattle and domestic reindeer. The underlying geology is fairly uniform, consisting of pyroxene granulite gneiss with small outcrops of mylonite and peridotite.

The Jostedalsbreen region, to the west of Jotunheimen, includes the largest icecap on mainland Europe, which gives rise to approximately 50 outlet glaciers. A number of glacier forelands occur below the treeline, which lies at about $850 \mathrm{~m}$. Data from the Bjørkhaug-i-Jostedalen meteorological station $(324 \mathrm{~m})$ indicates a mean annual air temperature of $+3.7^{\circ} \mathrm{C}$, a July mean of $+13.4^{\circ} \mathrm{C}$, a January mean of $-4.9^{\circ} \mathrm{C}$ and a mean annual precipitation of $1380 \mathrm{~mm}$ (Aune 1993; Førland 1993). Outdoor recreational pursuits and agriculture (grazing and arable) are the main land uses and a number of major hydro-electric power plants are also situated in the area. Approximately $1310 \mathrm{~km}^{2}$ of the Jostedalsbreen region, including most of the icecap has National Park status. The underlying geology is predominantly an acidic granitic gneiss.

Glacier forelands within these two regions (Fig. 1 and Table 1) provide an opportunity to examine pioneer vegetation across an altitudinal gradient of $80-1860 \mathrm{~m}$ with an east-west range of approximately $100 \mathrm{~km}$. Most of the glacier forelands have a general northerly or easterly aspect. The forelands, particularly within the pioneer zone closely adjacent to the glacier ice, are subject to direct and indirect disturbance due to the movement of the glacier, strong winds, low air temperatures, soil freezing and thawing, and continuous meltwater inflow during the summer (Matthews 1999). The newly deglaciated substrates in these paraglacial landscapes are in the process of adjusting to the removal of glacier ice and consist predominantly of unconsolidated, water-saturated sediments. A considerable body of research 


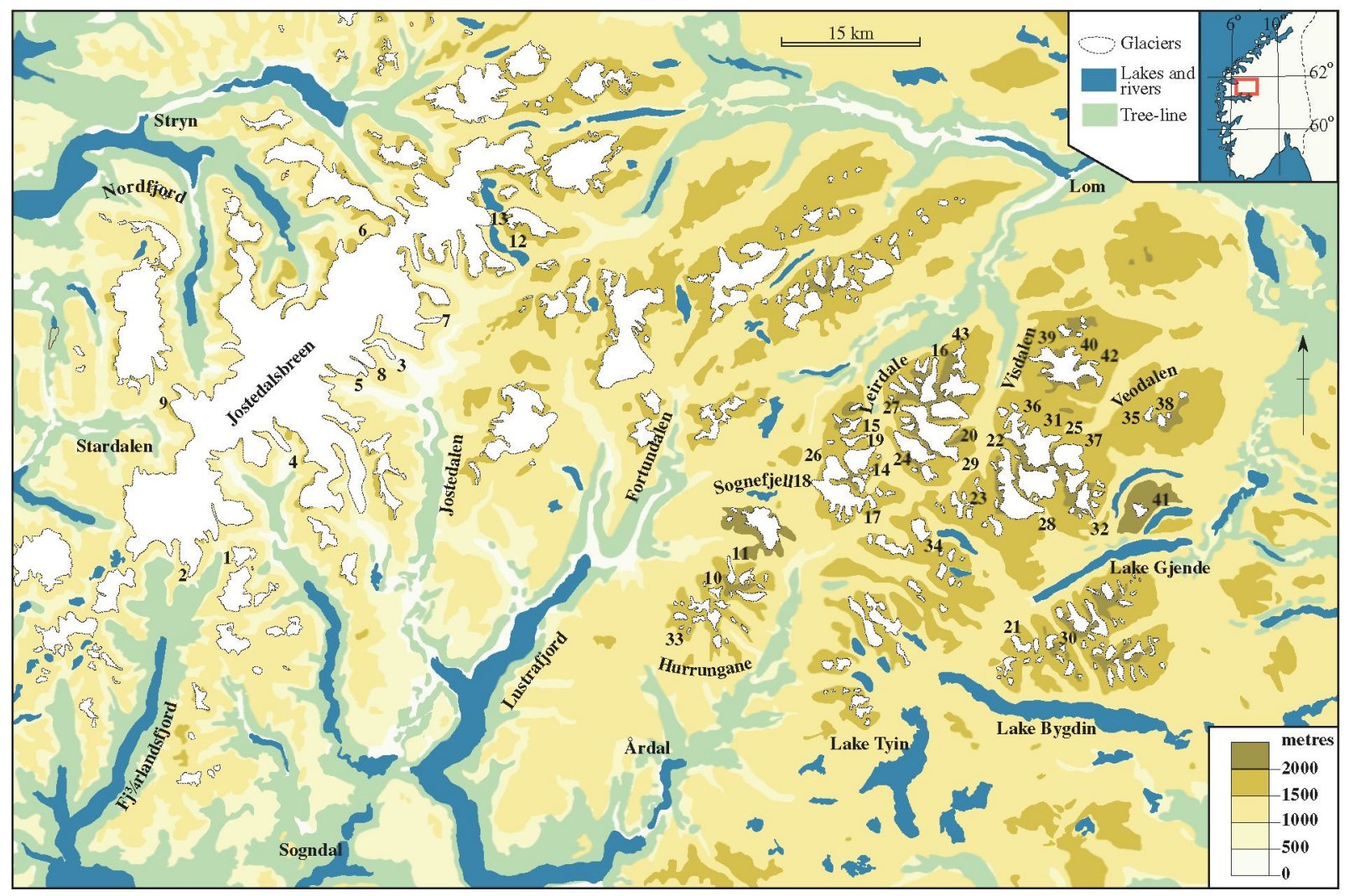

Fig. 1. Map of study area showing glacier forelands sampled. See Table 1 for key to numbered sites.

has been undertaken into many aspects of primary succession on glacier forelands in the Jotunheim and Jostedalsbreen regions (Matthews 1978b; 1979a; 1979b; 1979c; 1979d; Matthews \& Whittaker 1987; Whittaker 1989, 1991, 1993; Vetaas 1994, 1997; Haugland \& Beatty 2005). The patterns of successional change within this habitat are therefore relatively well understood and provide a framework within which to place detailed research on the pioneer stage.

\section{Fieldwork}

Pioneer species data were collected from 42 glacier forelands. Pioneer sites were defined as occupying the most recently deglacierized terrain close to the glacier front. The annual frontal variations of the small number of these glaciers that have been monitored (Nesje et al. 2008) show that glaciers in the region were retreating when transects were recorded between 1985 and 1988. Glacier retreat rates prior to this are consistent with terrain ages $<20$ years for the pioneer sites investigated (and much less than this for most of them). Altitude was estimated to the nearest $10 \mathrm{~m}$ a.s.l. from topographic maps with a contour interval of $20 \mathrm{~m}$. A point $5 \mathrm{~km}$ to the west of the most easterly foreland sampled (Haugabreen) was used as a reference for measuring distance east (continentality).

The sites represent the first zone/stage in a chronosequence, a widely used concept in the context of glacier foreland succession (Matthews 1992; Foster \& Tilman 2000). Species were recorded in transects of contiguous quadrats $\left(2 \times 0.5 \mathrm{~m}^{2}\right)$, starting with the individual plant closest to the glacier snout and continuing until 100 occurrences of species had been recorded on each site. The presence of each species in a quadrat was recorded, thus providing a measure of the relative local frequency of each species at that site. This rapid method of assessment allowed a large number of sites to be recorded in the sparsely vegetated terrain, is relatively objective, and avoids the necessity of delineating individual plants where growth form makes this difficult. Transect length and the distance from the glacier at which the first plant occurred (start distance from the glacier) are shown in Table 1.

The recording method resulted in a start distance ranging from 0.5 to $164.5 \mathrm{~m}$, transect length from 6.0 to $213 \mathrm{~m}$ and the distance from the glacier 
Table 1. Glacier forelands sampled, altitude (ma.s.1.), distance east $(\mathrm{km})$ (measured from a point $5 \mathrm{~km}$ west of Haugabreen foreland), mean Sørensen dissimilarity index [confidence interval $(\mathrm{CI})=95 \%$ ], transect length $(\mathrm{m})$ and start distance from glacier $(\mathrm{m})$.

\begin{tabular}{|c|c|c|c|c|c|c|}
\hline Code & Name & Altitude (m a.s.1.) & Distance east $(\mathrm{km})$ & Mean Sørensen $\pm 95 \%$ CI & Transect length (m) & Start distance $(\mathrm{m})$ \\
\hline 1 & Suphellabreen & 80 & 10 & $0.71 \pm 0.22$ & 15.0 & 0.5 \\
\hline 2 & Bøyabreen & 100 & 5.7 & $0.87 \pm 0.85$ & 6.0 & 0.5 \\
\hline 3 & Nigardsbreen & 400 & 29.6 & $0.64 \pm 0.02$ & 26.0 & 36.0 \\
\hline 4 & Austerdalsbreen & 420 & 19 & $0.62 \pm 0.12$ & 42.5 & 20.0 \\
\hline 5 & Bergsetbreen & 580 & 24.5 & $0.64 \pm 0.04$ & 17.0 & 1.0 \\
\hline 6 & B $\varnothing$ dalsbreen & 700 & 24.9 & $0.61 \pm 0.16$ & 10.0 & 16.0 \\
\hline 7 & Fåbergst $\varnothing$ lsbreen & 780 & 35.2 & $0.63 \pm 0.07$ & 125.0 & 35.0 \\
\hline 9 & Haugabreen & 900 & 4.7 & $0.56 \pm 0.33$ & 18.0 & 20.0 \\
\hline 10 & Ringsbreen & 1100 & 60.5 & $0.65 \pm 0.01$ & 58.0 & 0.5 \\
\hline 11 & Styggedalsbreen & 1280 & 65.3 & $0.61 \pm 0.15$ & 24.5 & 27.0 \\
\hline 12 & Vivakulen & 1280 & 39.9 & $0.88 \pm 0.90$ & 60.0 & 20.0 \\
\hline 13 & Austdalsnutin & 1300 & 40.1 & $0.77 \pm 0.47$ & 86.0 & 34.0 \\
\hline 14 & Storbreen & 1380 & 80.7 & $0.62 \pm 0.12$ & 33.5 & 40.0 \\
\hline 15 & Hurrbreen & 1380 & 80.2 & $0.54 \pm 0.43$ & 23.5 & 44.5 \\
\hline 16 & Storgjuvbreen & 1380 & 88 & $0.64 \pm 0.02$ & 19.5 & 21.0 \\
\hline 18 & $\mathrm{~B} \not$ verbreen & 1420 & 74.4 & $0.62 \pm 0.12$ & 46.5 & 9.0 \\
\hline 19 & Veslbreen & 1420 & 80.4 & $0.72 \pm 0.27$ & 9.5 & 7.5 \\
\hline 20 & Tverråbreen & 1440 & 90.1 & $0.56 \pm 0.34$ & 57.0 & 67.0 \\
\hline 21 & Slettmarksbreen & 1460 & 95.7 & $0.65 \pm 0.02$ & 43.0 & 32.0 \\
\hline 22 & Hellstugubreen & 1480 & 95.3 & $0.61 \pm 0.16$ & 39.0 & 54.0 \\
\hline 23 & Visbreen & 1500 & 89.6 & $0.61 \pm 0.14$ & 66.0 & 9.0 \\
\hline 24 & S Illåbreen & 1520 & 84.7 & $0.64 \pm 0.01$ & 72.5 & 27.5 \\
\hline 25 & Veobreen & 1530 & 100.9 & $0.59 \pm 0.21$ & 65.0 & 59.0 \\
\hline 26 & Leirbreen & 1540 & 76.3 & $0.62 \pm 0.12$ & 34.5 & 41.5 \\
\hline 27 & N Illåbreen & 1580 & 85.1 & $0.60 \pm 0.19$ & 91.0 & 53.0 \\
\hline 28 & Memurbreen & 1580 & 98.7 & $0.57 \pm 0.32$ & 36.5 & 22.0 \\
\hline 29 & Bukkeholsbreen & 1600 & 90.1 & $0.56 \pm 0.36$ & 14.0 & 19.5 \\
\hline 30 & Svartdalsbreen & 1600 & 100 & $0.57 \pm 0.29$ & 38.5 & 80.5 \\
\hline 31 & Styggebreen & 1600 & 92.2 & $0.63 \pm 0.06$ & 59.5 & 21.0 \\
\hline 32 & Tjukningsbreen & 1600 & 104.2 & $0.57 \pm 0.29$ & 21.0 & 45.0 \\
\hline 33 & Austabotbreen & 1620 & 59.8 & $0.71 \pm 0.22$ & 169.0 & 40.0 \\
\hline 37 & $\mathrm{~N}$ Veobreen & 1700 & 98.7 & $0.69 \pm 0.17$ & 81.0 & 25.5 \\
\hline 38 & E Nautgardsbr. & 1730 & 111.7 & $0.68 \pm 0.12$ & 44.0 & 28.5 \\
\hline 39 & W Grotbreen & 1770 & 99.1 & N/A & $N / A$ & $\mathrm{~N} / \mathrm{A}$ \\
\hline 40 & E Grotbreen & 1780 & 103.3 & $0.63 \pm 0.07$ & 39.5 & 19.5 \\
\hline 41 & Besshöbreen & 1780 & 109.9 & $0.84 \pm 0.75$ & 88.0 & 30.0 \\
\hline 42 & Gräsubreen & 1800 & 104.2 & $0.71 \pm 0.25$ & 133.5 & 164.5 \\
\hline 43 & Gjuvbreen & 1860 & 90.5 & $0.70 \pm 0.19$ & 87.0 & 50.0 \\
\hline
\end{tabular}

to the end of each transect from 6.5 to $298.0 \mathrm{~m}$. This variability is in part accounted for by differences in the rate of retreat of the glaciers; relatively long transects generally correspond with the relatively large glaciers where retreat rates were greater (e.g. Fåbergst $ø l$ sbreen), glacier forelands with large areas of uncolonisable bedrock, open water or boulders (e.g. Sandelvbreen), or forelands disturbed by geomorphic processes such as frost action at high altitudes (e.g. Gråsubreen).

Variability in transect length was also affected by local habitat conditions, including major disturbances such as shifting meltwater streams, and inhospitable substrates such as bedrock outcrops. The accidented nature of glacier forelands means that a degree of habitat heterogeneity is inevitable in this environment (Matthews 1999). However, transects were located to minimise site-specific environmental variation. The optimal location was a flat, even surface, avoiding streams, pools and lakes to ensure similar moisture conditions. The preferred substrate was till (glacial sediment characterised by a mixture of grain sizes including silt, sand and cobbles) that had stabilised and had not been affected by glaciofluvial erosion or other geomorphic disturbances.

Nomenclature conforms with Lid \& Lid (1994). Information on key dispersal agents was obtained from an online database at the University of York (Peat \& Fitter 2007). 


\section{Data analysis}

All data analyses were carried out using PCORD Version 4.33 (McCune \& Mefford 1999), Canoco Version 4.54 (ter Braak \& Šmilauer 2006) and Microsoft Excel 2002.

Overall variability was measured using Sørensen distance based on species abundance (Bray \& Curtis 1957), converted to percentage dissimilarity. This is a relatively sensitive measure of heterogeneity in large datasets, gives less weight to outliers than Euclidean distance (McCune \& Grace 2002) and has performed well in comparisons with other distance measures (Faith et al. 1987).

The relationship between glacier foreland sites in terms of their species composition was examined using non-metric multidimensional scaling (NMS). Sites were therefore plotted according to their rank order of compositional distances rather than absolute distances, which improves the ability to extract information from non-linear relationships. This overcomes the inherent limitation of dissimilarity coefficients in expressing large distances when sites with no species in common have a fixed maximum distance (Mather 1976; Kruskal \& Wish 1978). The most thorough PC-ORD autopilot option of NMS was used to ordinate the sites ( 40 runs with real data, 50 randomised runs, a maximum of 400 iterations and an instability criterion of 0.00001). Randomisation of the data with a Monte Carlo test allowed assessment of whether the NMS ordination axes have lower stress than expected by chance. Stress levels below $20 \%$ were considered to provide a satisfactory quantitative solution (Clarke 1993), with levels approaching $20 \%$ providing a qualitative guide to the inter-relationships between sites. Following McCune \& Grace (2002), a final instability of $10^{-4}$ or less was considered acceptable. How well the relationships between sites in the numerical solution represent their relationships in the original dissimilarity matrix was assessed by the coefficient of determination $\left(r^{2}\right)$ between distances in ordination space and distances in the original data (McCune \& Grace 2002).

Cluster analysis was selected to complement NMS ordination, providing a site classification based on the Sørensen proportion coefficient. PCORD software uses the clustering algorithm of Wishart (1969) and Post \& Sheperd (1974). Flexible sorting (with $\beta=-0.25$ ) was used, which provides a space-conserving method (McCune \& Grace 2002). This means that the distances between units are not significantly distorted by the formation of each new group. Determining the number of groups at which to analyse a dendrogram is always a compromise between obtaining maximum homogeneity and minimizing the number of groups. Three approaches were adopted in this study: (1) a multiresponse permutation procedure (MRPP) (Mielke \& Berry 2001) to compare average within-group distances with those resulting from random combinations of the data; (2) indicator species analysis (Dufrene \& Legendre 1997) to assess the collective indicator value at each level of clustering; and (3) a graphical representation of group centroids on the NMS diagram defined by the mean axis scores of each cluster. In the diagram, confidence ellipses indicate \pm 2 SD from the mean and therefore enclose approximately $95 \%$ of sites within each cluster.

The MRPP method (Mielke \& Berry 2001) produces a measure of chance-corrected withingroup agreement ( $A$-value), which is independent of sample size, and a $T$-value, which provides a measure of the separation between groups. The latter is the difference between the observed and expected within-group distances divided by the square root of the variance in the expected within-group distance. The change in $A$ - and $T$-values at each level of clustering is used as a measure of the effect on withingroup homogeneity and between-group separation from adding an additional group.

Indicator species analysis (Dufrene \& Legendre 1997) was used to identify characteristic species for the description and ecological assessment of groups, and to provide a measure of how well species are separated between groups. The statistical significance of indicator values was assessed with a Monte Carlo randomisation test, with the null hypothesis that the species has no indicator value. Groups were also analysed geographically, according to altitude and distance east (direct gradient analysis).

Variance partitioning as a component of canonical correspondence analysis (CCA) was used to quantify the relative contributions of altitude and continentality to the total variation in species abundances. Variance partitioning was carried out using Canoco 4.54 software (ter Braak \& Šmilauer 2006) and the technique is described in Økland \& Eilertsen (1994) and Lepš \& Šmilauer (2003).

\section{Results}

A total of 71 species was recorded on the 42 glacier foreland pioneer sites, with seven species occurring on $>50 \%$ of sites, 18 species on at least $20 \%$ of sites and 33 on fewer than $5 \%$ of sites. Table 2 
Table 2. Species recorded on glacier foreland pioneer sites, $\%$ sites at which the species is present and mean abundance. Nomenclature conforms with Lid \& Lid (1994).

\begin{tabular}{|c|c|c|c|}
\hline Code & Species & $\%$ sites & Mean abundance \\
\hline Poaalp & Poa alpina & 92.86 & 18.36 \\
\hline Oxydig & Oxyria digyna & 85.71 & 13.17 \\
\hline Desalp & Deschampsia alpina & 83.33 & 9.93 \\
\hline Fesovi & Festuca ovina & 80.95 & 5.41 \\
\hline Ceralp & Cerastium alpinum & 76.19 & 8.91 \\
\hline Trispi & Trisetum spicatum & 59.52 & 7.55 \\
\hline Rangla & Ranunculus glacialis & 57.14 & 7.57 \\
\hline Salgla & Salix glauca & 47.62 & 1.95 \\
\hline Araalp & Arabis alpina & 45.24 & 4.50 \\
\hline Saxces & Saxifraga cespitosa & 45.24 & 1.86 \\
\hline Saxste & Saxifraga stellaris & 38.10 & 3.41 \\
\hline Saxopp & Saxifraga oppositifolia & 38.10 & 1.71 \\
\hline Silaca & Silene acaulis & 35.71 & 0.95 \\
\hline Epiana & Epilobium anagallidifolium & 28.57 & 1.52 \\
\hline Luzspi & Luzula spicata & 26.19 & 1.14 \\
\hline Salher & Salix herbacea & 26.19 & 0.98 \\
\hline Phlalp & Phleum alpinum & 21.43 & 0.98 \\
\hline Omanor & Omalotheca norvegica & 21.43 & 0.41 \\
\hline Omasup & Omalotheca supina & 19.05 & 0.62 \\
\hline Saxriv & Saxifraga rivularis & 16.67 & 0.83 \\
\hline Luzare & Luzula arcuata & 16.67 & 0.55 \\
\hline Chaang & Chamerion angustifolium & 14.29 & 0.74 \\
\hline Athdis & Athyrium distentifolium & 14.29 & 0.55 \\
\hline Arapet & Arabidopsis petraea & 11.90 & 0.21 \\
\hline Rumlla & Rumex acetosella & 9.52 & 0.48 \\
\hline Alcalp & Alchemilla alpina & 9.52 & 0.31 \\
\hline Crycri & Cryptogramma crispa & 9.52 & 0.17 \\
\hline Saxniv & Saxifraga nivalis & 9.52 & 0.14 \\
\hline Taragg & Taraxacum aggregate & 9.52 & 0.14 \\
\hline Rhoros & Rhodiola rosea & 9.52 & 0.10 \\
\hline Saxcer & Saxifraga cernua & 7.14 & 0.69 \\
\hline Polviv & Polygonum viviparum & 7.14 & 0.29 \\
\hline Carbig & Carex bigelowii & 7.14 & 0.19 \\
\hline Gymdry & Gymnocarpium dryopteris & 7.14 & 0.12 \\
\hline Minbif & Minuartia biflora & 7.14 & 0.12 \\
\hline Veralp & Veronica alpinum & 7.14 & 0.12 \\
\hline Betpub & Betula pubescens & 7.14 & 0.10 \\
\hline Leoaut & Leontodon autumnalis & 7.14 & 0.07 \\
\hline Narstr & Nardus siricta & 4.76 & 0.26 \\
\hline Agrcap & Agrostis capillaris & 4.76 & 0.19 \\
\hline Juntrf & Juncus trifidus & 4.76 & 0.12 \\
\hline Saxazo & Saxifraga azoides & 4.76 & 0.07 \\
\hline Camrot & Campanula rotundifolia & 4.76 & 0.05 \\
\hline Empher & Empetrum hermaphroditum & 4.76 & 0.05 \\
\hline Sagsag & Sagina saginoides & 4.76 & 0.05 \\
\hline Visalp & Viscaria alpina & 4.76 & 0.05 \\
\hline Desces & Deschampsia cespitosa & 2.38 & 0.55 \\
\hline Cercer & Cerastium cerastoides & 2.38 & 0.31 \\
\hline Ranrep & Ranunculus repens & 2.38 & 0.26 \\
\hline Cirhet & Cirsium heterophyllum & 2.38 & 0.19 \\
\hline Wooalp & Woodsia alpina & 2.38 & 0.17 \\
\hline Viobif & Viola biflora & 2.38 & 0.14 \\
\hline Alcglo & Alchemilla glomerulans & 2.38 & 0.12 \\
\hline Alnine & Alnus incana & 2.38 & 0.12 \\
\hline Phycae & Phyllodoce caerulea & 2.38 & 0.07 \\
\hline Loteor & Lotus corniculatus & 2.38 & 0.05 \\
\hline Stearv & Siellaria arvensis & 2.38 & 0.05 \\
\hline Antdio & Antennaria dioeca & 2.38 & 0.02 \\
\hline Antodo & Anthoxanthum odoratum & 2.38 & 0.02 \\
\hline Carbel & Cardamine bellidifolia & 2.38 & 0.02 \\
\hline Epihor & Epilobium hornemannii & 2.38 & 0.02 \\
\hline Equsci & Equisetum scirpoides & 2.38 & 0.02 \\
\hline Hiealp & Hieracium alpinum & 2.38 & 0.02 \\
\hline Ortsec & Orthilia secunda & 2.38 & 0.02 \\
\hline Petfri & Petasites frigidus & 2.38 & 0.02 \\
\hline Sallan & Salix lanata & 2.38 & 0.02 \\
\hline
\end{tabular}

Table 2. (Continued)

\begin{tabular}{llcc}
\hline Code & Species & $\%$ sites & Mean abundance \\
\hline Sedvil & Sedum villosum & 2.38 & 0.02 \\
Sibpro & Sibbaldia procumbens & 2.38 & 0.02 \\
Sildio & Silene dioica & 2.38 & 0.02 \\
Solvir & Solidago virgaurea & 2.38 & 0.02 \\
Urtdio & Uritica dioica & 2.38 & 0.02 \\
\hline
\end{tabular}

lists the species recorded, their percentage frequency (the percentage of sites containing that species) and mean abundance (the mean relative frequency of each species). Poa alpina has the highest frequency and mean abundance, occurring on $93 \%$ of sites with a mean abundance of $18 \%$. Three other species occur with a frequency $>80 \%$ : Oxyria digyna $(86 \%)$, Deschampsia alpina (83\%) and Festuca ovina $(81 \%)$. Of these, $O$. digyna has the highest mean abundance at $13 \%$. Three of the four most frequent species are Poaceae, with two other grasses also occurring at relatively high frequencies: Trisetum spicatum (60\%) and Phleum alpinum (21\%). Of the remaining species recorded on $>20 \%$ of foreland pioneer sites, Cerastium alpinum has the highest frequency at $76 \%$, followed by Ranunculus glacialis $(57 \%)$, Salix glauca (48\%) and Arabis alpina $(45 \%)$. C. alpinum, T. spicatum and $R$. glacialis also have high mean relative abundances at $9 \%, 8 \%$ and $8 \%$, respectively. S. herbacea is present on $26 \%$ of glacier foreland pioneer sites and three Saxifraga spp. also occur with relatively high frequency: S. cespitosa $(45 \%), S$. oppositifolia $(38 \%)$ and S. stellaris (38\%). Silene acaulis, Epilobium anagallidifolium, Luzula spicata and Omalotheca norvegica were also found on $>20 \%$ of sites. The glacier foreland pioneer vegetation is therefore predominantly herbaceous, consisting of both grasses and forbs, with the shrubs $S$. glauca and $S$. herbacea also attaining high relative abundances. All species are perennials and the majority are adapted for either water or wind dispersal and also have the capacity for vegetative propagation.

The mean Sørensen distance between glacier foreland sites, which quantifies the overall variability within this dataset, is $0.65 \pm 0.02 \quad(95 \%$ confidence interval). Outlier analysis revealed that the three forelands with the greatest mean Sørensen distances from other sites are Vivakulen (mean distance $=0.88 \pm 0.03$ ), B $\varnothing$ yabreen (mean distance $=$ $0.87 \pm 0.03$ ) and Besshöbreen (mean distance $=$ $0.84 \pm 0.02$ ). Vivakulen has only two species present (Luzula arcuata and O. digyna); Bøyabreen has 22 species, eight of which do not occur on other forelands; and Besshöbreen is unusual in having a 
relative frequency of $86 \% R$. glacialis and only two other species ( $P$. alpina and $F$. ovina). Because these three forelands lie within $\pm 3 \mathrm{SD}$ limits, they are considered to be extremes rather than outliers and are therefore included in subsequent analyses. Bøyabreen, with eight rare species, is a possible candidate for exclusion as an outlier but, as its mean distance from other sites is lower than that of Vivakulen, such exclusion cannot be justified.

NMS ordination with all sites and species included (Fig. 2) resulted in a stress of $19.7 \%$ for two dimensions $(P=0.0196)$ and $13.7 \%$ for three dimensions $(P=0.0196)$. Instability reached a level of $10^{-5}$ for three dimensions after 112 iterations and $10^{-4}$ for two dimensions after 50 iterations. These stress levels suggest a meaningful visual representation despite a lack of clear structure in the variation in species composition between sites. The ordination was assessed further by calculating coefficients of determination for the correlation between ordination distances and distances in the original n-dimensional space. The cumulative $r^{2}$ for the three-dimensional ordination is 0.81 , while that for two-dimensional ordination is 0.76 . There is therefore an increase in stress of only $6 \%$ and a reduction in the coefficient of determination of only $5 \%$ if two axes are used instead of three. Instability is higher for two dimensions than for three but both are within acceptable limits. The two-dimensional ordination diagram is therefore preferred because the three-dimensional representation does not

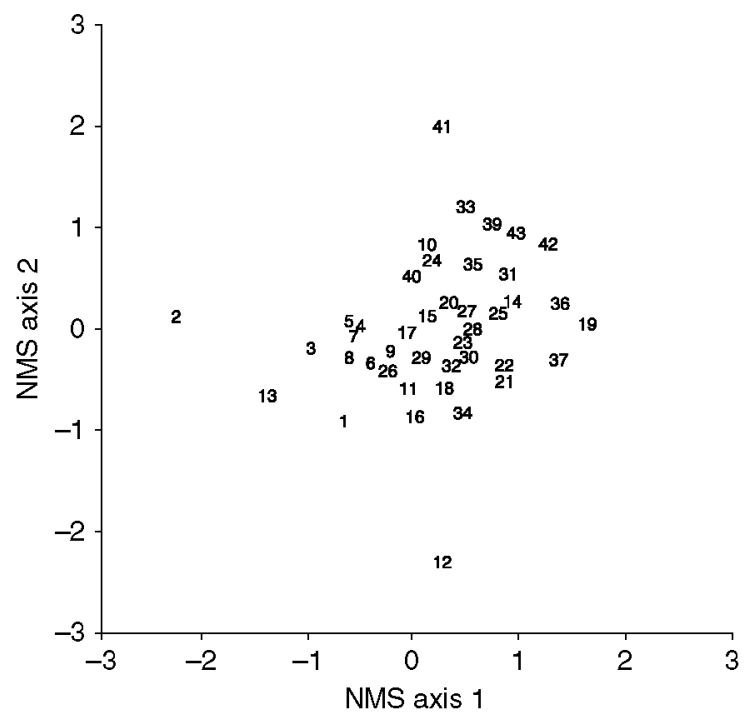

Fig. 2. Non-metric multidimensional scaling of glacier foreland pioneer sites. See Table 1 for key to numbered sites. provide an appreciable improvement and is more difficult to interpret.

There were no obvious clusters or clear divisions between groups of sites that could form the basis for classification (Fig. 2). However, the three sites that were identified as extremes are clearly separated from each other and from the majority of other sites on the ordination diagram. NMS ordination with rare species excluded (i.e. those recorded on $<5 \%$ sites) failed to reach a stable solution. At the three-group level, Vivakulen and Bøyabreen form a separate two-site group, which subsequently forms two single-site groups at the five-group level. The initial clustering of these two sites reflects their dissimilarity from other sites in terms of species composition rather than any similarity between them. Furthermore, the subsequent formation of single-site groups means that higher levels are not suitable for MRPP and indicator species analysis. At the four-group level, Besshöbreen forms a twosite group with Austabotbreen. Both these forelands have high relative frequencies of Rancunculus glacialis but are not otherwise unusual.

MRPP analysis was therefore carried out up to the four-group level only: above this level, as outlined above, the data split into single-site groups. The MRPP statistics reveal that separation between groups is generally low $(T=-12.1$ to -14.3$)$ (Table 3) and the $T$ statistic is lower for three groups than for two or four, indicating less separation at the three-group level. Assessment of the relative numbers of indicator species and the sum of significant indicator values at each level of clustering (Table 3) also shows that the three-group level gives a lower value for both factors than the two- or four-group levels. The two-group level is therefore considered most appropriate, given the relatively small number of sites, but the four-group level is also examined. As ordination did not reveal a strong structure in the data, it is likely that none of the groups is a natural group and that division of the sites into groups is essentially arbitrary.

Examination of the group centroids at the twogroup level (Fig. 3) shows that sites in group 2A tend to have lower scores on both axes than sites in group 2B. The ordination distance between sites at the border between the two groups does not show any discontinuity and, moreover, there do not appear to be areas of tighter clustering within either of the two groups. Furthermore, assessment of indicator species for these two groups (Table 4) suggests that those species indicative of group $2 \mathrm{~B}$ are more typical of mid- to high-alpine zones, e.g. Saxifraga cespito$s a$, Arabis alpina and $R$. glacialis, while those 
Table 3. Number of significant indicator values, sum of significant indicator values and multi-response permutation procedure $T$ - and $A$-values for glacier foreland pioneer cluster analysis groups.

\begin{tabular}{|c|c|c|c|c|c|}
\hline Number of groups & No. of significant indicator values & Sum of significant indicator values & $T$-value & $A$-value & $P$ \\
\hline 2 & 16 & 806 & -14.31 & 0.09 & $<0.001$ \\
\hline 3 & 6 & 433 & -12.15 & 0.13 & $<0.001$ \\
\hline
\end{tabular}

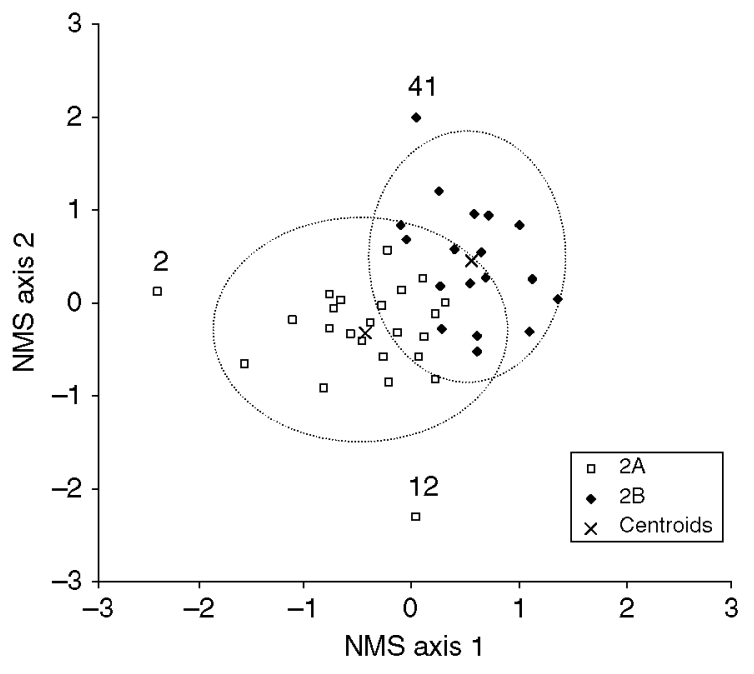

Fig. 3. Non-metric multidimensional scaling ordination of glacier foreland pioneer sites with two cluster analysis groups (2A and $2 \mathrm{~B})$ superimposed. Ellipses indicate \pm 2 SD from each group centroid. See Table 1 for key to numbered sites.

indicative of group 2A are more typical of sites with higher moisture, e.g. Saxifraga stellaris, Omalotheca supina and E. anagallidifolium. A comparison of indicator values for each species between the two groups confirms that the majority of group $2 \mathrm{~A}$ indicators are absent from group $2 \mathrm{~B}$ but not vice versa. This also suggests that these groups are part of a continuum of variation and hence are best considered sub-communities or variants. Naming of these two groups on the basis of their most important indicator species results in the $D$. alpina- $O$. digyna sub-community (2A) and the $S$. cespitosa-T. spicatum sub-community (2B).

When sites within these two sub-communities were plotted by their altitude and continentality (Fig. 4), the resulting direct gradient analysis shows that the D. alpina-O. digyna sub-community occurs across the entire range of altitudes and distances east, whereas the $S$. cespitosa-T. spicatum sub-community occurs only at altitudes of $1100 \mathrm{~m}$ and above and at a minimum distance east of $60 \mathrm{~km}$. These results indicate that, rather than the two sub-
Table 4. Significant indicator values (IV) $(\%)$ for the two glacier foreland pioneer groups.

\begin{tabular}{lrrl}
\hline Species & \multicolumn{2}{l}{ Observed IV (\%) } & $P$ \\
\cline { 2 - 3 } & 2A & 2B & \\
\hline Deschampsia alpina & 77 & 13 & 0.001 \\
Oxyria digyna & 72 & 17 & 0.003 \\
Saxifraga stellaris & 62 & 0 & 0.001 \\
Epilobium anagallidifolium & 40 & 0 & 0.011 \\
Omalotheca supina & 33 & 0 & 0.013 \\
Phleum alpinum & 32 & 0 & 0.021 \\
Omalotheca norvegica & 31 & 0 & 0.029 \\
Chamerion angustifolium & 25 & 0 & 0.043 \\
Athyrium distentifolium & 25 & 0 & 0.045 \\
Saxifraga cespitosa & 2 & 69 & 0.001 \\
Trisetum spicatum & 6 & 68 & 0.003 \\
Poa alpina & 29 & 67 & 0.003 \\
Arabis alpina & 4 & 58 & 0.002 \\
Ranunculus glacialis & 11 & 57 & 0.012 \\
Saxifraga oppositifolia & 3 & 56 & 0.002 \\
Saxifraga rivularis & 0 & 33 & 0.01 \\
\hline
\end{tabular}

communities being clearly separated in terms of altitude or continentality, the latter sub-community has a more restricted distribution. This provides further evidence of continuity within the glacier foreland pioneer community as a whole.

Clustering of the glacier foreland pioneer sites into four groups (Fig. 5) produced groups $4 \mathrm{~A}$ to $4 \mathrm{C}$ (which again appear to be divided along a continuum rather than forming clusters of sites) and group 4D, which is based on a very small number of sites. The results of indicator species analysis (Table 5) show that group $4 \mathrm{C}$ has the largest number of indicators, all of which (with the exception of Saxifraga stellaris with an indicator value of $14 \%$ in group 4A) are either absent from or have values of $10 \%$ or less in other groups. Group $4 \mathrm{~A}$ has only two significant indicator species: $O$. digyna $(53 \%)$, which also has a fairly high value $(23 \%)$ in group $4 \mathrm{C}$, and D. alpina $(52 \%)$, which has a value of $27 \%$ in group 4C. Group 4B has three indicator species: T. spicatum (74\%), Arabis alpina (64\%) and S. cespitosa $(58 \%)$, none of which has a value of $>10 \%$ in another group. Group 4D is characterised by one species, $R$. glacialis $(87 \%)$, which has low indicator values within two of the other groups. On the basis 


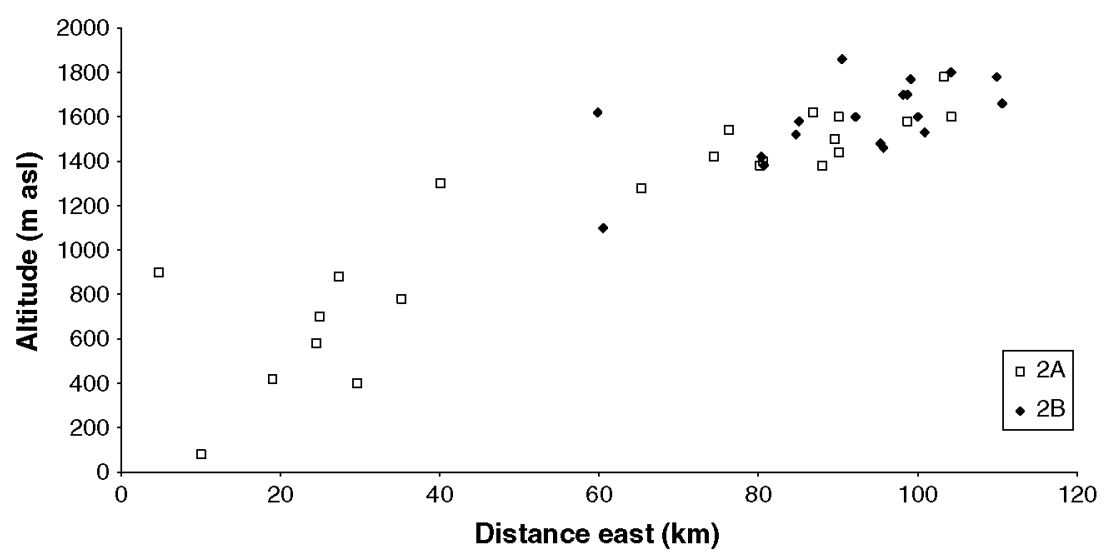

Fig. 4. Altitude and distance east of the two glacier foreland pioneer sub-communities (2A and B).

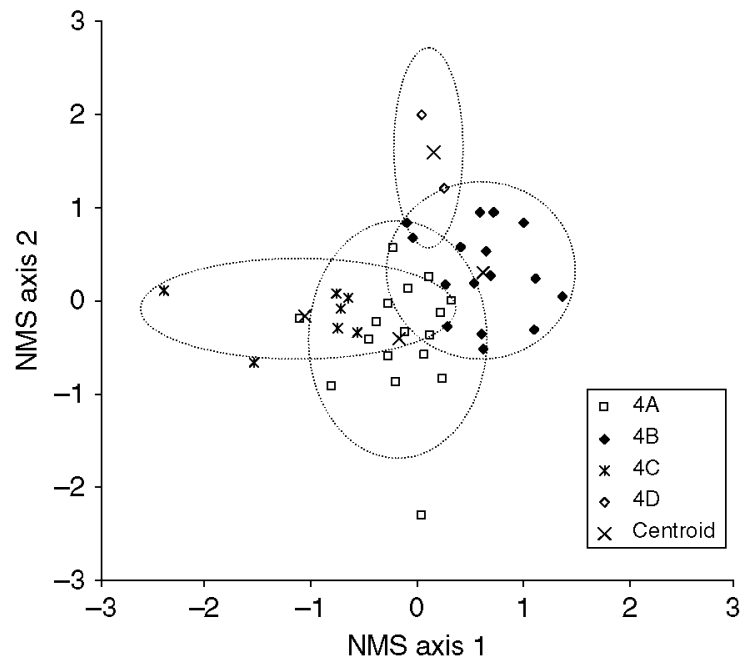

Fig.5. Non-metric multidimensional scaling of glacier foreland pioneer sites with four cluster analysis groups (4A-D) superimposed. Ellipses indicate \pm 2 SD from each group centroid.

of this evidence, there seems little justification for subdivision into four sub-groups. Group 4A is characterised solely on the relative abundance of two widespread species, while group 4D consists of only two sites and is characterised by a single species. Groups 4A, 4B and 4C therefore appear to be part of a continuum of change, rather than distinct communities.

Direct gradient analysis at the four-group level (Fig. 6) shows that group 4A consists of sites with a broad altitudinal and regional range, while group $4 \mathrm{C}$ is restricted to sites to the west of the region (a maximum of $40 \mathrm{~km}$ east), the majority of which lie below $1000 \mathrm{~m}$. Group 4D is not separated from groups $4 \mathrm{~A}$ or $4 \mathrm{~B}$ in terms of altitude or continentality. At the four-group level, therefore, only
Table 5. Significant indicator values (IV) (\%) for the four glacier foreland pioneer groups.

\begin{tabular}{lrrrrr}
\hline Species & \multicolumn{3}{l}{ Observed IV (\%) } & $P$ \\
\cline { 2 - 5 } & 4A & 4B & 4C & 4D & \\
\hline Oxyria digyna & 53 & 12 & 23 & 1 & 0.043 \\
Deschampsia alpina & 52 & 9 & 27 & 2 & 0.023 \\
Trisetum spicatum & 8 & 74 & 0 & 0 & 0.004 \\
Arabis alpina & 6 & 64 & 0 & 0 & 0.027 \\
Saxifraga cespitosa & 3 & 58 & 0 & 9 & 0.035 \\
Salix glauca & 6 & 5 & 71 & 0 & 0.003 \\
Chamerion angustifolium & 0 & 0 & 71 & 0 & 0.019 \\
Epilobium anagallidifolium & 4 & 0 & 69 & 0 & 0.012 \\
Omalotheca supina & 3 & 0 & 66 & 0 & 0.022 \\
Saxifraga stellaris & 14 & 0 & 63 & 0 & 0.018 \\
Phleum alpinum & 2 & 0 & 62 & 0 & 0.025 \\
Cryptogramma crispa & 0 & 0 & 57 & 0 & 0.011 \\
Athyrium distentifolium & 1 & 0 & 53 & 0 & 0.019 \\
Omalotheca norvegica & 7 & 0 & 39 & 0 & 0.047 \\
Ramunculus glacialis & 4 & 4 & 0 & 87 & 0.001 \\
\hline
\end{tabular}

group $4 \mathrm{C}$ has a relatively discrete altitudinal and regional distribution.

Variance partitioning of the dataset showed that, of the total variation in species abundance, altitude alone accounts for $24 \%$, distance east for $18 \%$, and the component shared by altitude and distance east represents $17 \%$ (Table 6). (These factors account for $37 \%$ (altitude), $29 \%$ (distance east) and $27 \%$ (shared component) of the explained variation.)

\section{Discussion}

\section{The nature of pioneer species}

Many species have been recorded in the pioneer zones of these glacier forelands (71 species). This number is, however, lower than on roadside sites 


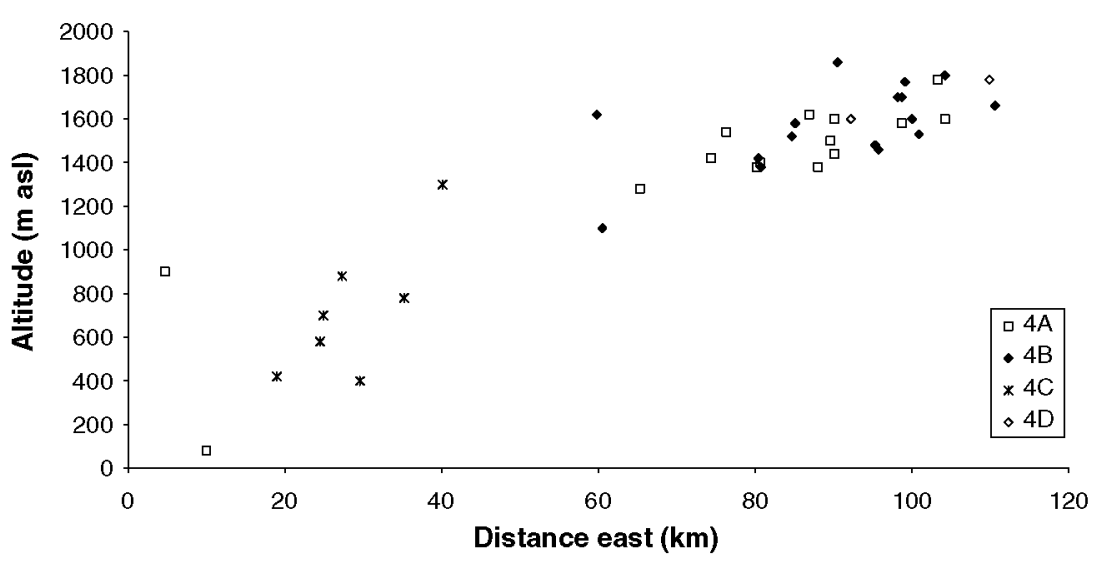

Fig. 6. Altitude and distance east of the four glacier foreland pioneer sub-communities.

Table 6. Variance explained (also expressed as \% of total inertia) by altitude and distance east for the glacier foreland pioneer dataset. VE, variance explained; TI, total inertia; $A$, altitude; $E$, distance east. All values are significant at $P=0.002$.

\begin{tabular}{ll}
\hline Variable & VE $(\%$ TI $)$ \\
\hline$A$ & $0.0045(0.40)$ \\
$E$ & $0.0038(0.35)$ \\
$A \cap E$ & $0.0019(0.17)$ \\
$A \mid E$ & $0.0026(0.24)$ \\
$E \mid A$ & $0.0020(0.18)$ \\
\hline
\end{tabular}

(152 species) in the same study area within a similar altitudinal range (Robbins 2007), suggesting that glacier foreland pioneer vegetation is perhaps less variable in terms of species composition than roadside pioneer vegetation. This is supported by a lower mean Sørensen dissimilarity of $65 \%$ on the forelands compared with $81 \%$ on roadsides, and also by the comparable value of $70 \%$ for sites deglaciated for up to 23 years on Coleman Glacier foreland, Washington (Jones \& del Moral 2005).

The most frequent pioneer species are those identified by Matthews (1978a) on Storbreen glacier foreland, i.e. a "core" group of pioneer species consisting of Saxifraga stellaris, $D$. alpina and Cerastium spp, with $S$. cespitosa and Arabis alpina also being confined to the youngest terrain. $O$. digyna, Cardamine bellidifolia, Luzula arcuata, L. spicata and $R$. glacialis were found in conjunction with the "core" pioneers, and $P$. alpina and $T$. spicatum were commonly found in the pioneer zone at Storbreen. Eight of these species were recorded on at least $45 \%$ of the $\mathbf{4 2}$ glacier forelands in this study, with S. stellaris, L. spicata and L. arcuata recorded on $38 \%$, $26 \%$ and $17 \%$, respectively. Only two frequent pio- neer species ( $F$. ovina and $S$. glauca) were not included in Matthews' (1978a) pioneer group. The pioneer species identified by Matthews at Storbreen are therefore confirmed as being highly representative of glacier foreland pioneer sites within the study area.

The dominance of the pioneer vegetation by perennial grasses and forbs is consistent with previous findings (Matthews 1992; Chapin III 1993). Perennial plants are known to predominate in alpine tundra where the low summer temperatures are not sufficient for annuals to reach maturity and set seed in a single season (Bliss 1971). The dominance of perennial species on glacier forelands at all altitudes therefore suggests that glacier proximity has an effect on species composition at this early stage.

The prevalence of wind- and water-dispersed seeds emphasises the strong influence of environmental factors on the spread of pioneer species (Jumpponen et al. 1999). Dispersal mechanisms have been addressed in several studies, and wind dispersal has been cited as a major mode of pioneer immigration onto glacier forelands (Ryvarden 1971; Stöcklin \& Bäumler 1996). Glacial meltwater streams and rivers are considered important dispersal routes for species with or without adaptive structures (Stöcklin \& Bäumler 1996). Studies of pioneer vegetation on pumice at Mount St. Helens (del Moral \& Jones 2002) and sand dunes in France and Belgium (Bossuyt et al. 2003) also found initial domination by species with good dispersal. The high incidence of capacity to reproduce vegetatively in pioneer species is consistent with the findings of Whittaker (1993) on Storbreen glacier foreland. However, he found that, although many pioneer species can propagate vegetatively, they dominate 
only on relatively undisturbed sites. In an environment characterised by repeated disturbance and infertility, it is possible that these species constitute a stress-tolerant, disturbance-tolerant group (sensu Grime 1979). Ecological traits will be discussed in a future paper, which will present the results of analysis of Ellenberg indicator values (Ellenberg 1974) along glacier foreland chronosequences.

\section{The nature of the pioneer community}

The ordination and classification results both suggest that this dataset consists broadly of $P$. alpina-O. digyna vegetation characterised by variation in species composition within a continuum. The necessity of including rare species in order to reach a stable NMS ordination points to a relatively weak structure in these data (McCune \& Grace 2002). Furthermore, MRPP of the cluster analysis groups showed no sharp improvements in withingroup agreement or between-group separation as additional groups are recognised.

Classification can provide a useful, if somewhat arbitrary, clustering of the data into two subcommunities: D. alpina-O. digyna (2A), which has a wide altitudinal and geographical distribution, and $S$. cespitosa-T. spicatum (2B), which occurs only in Jotunheimen above the treeline.

The findings have parallels with those of Matthews (1978b) and Whittaker (1993). Two indicator species within the $S$. cespitosa-T. spicata subcommunity ( $S$. cespitosa and Arabis alpina) were identified by both of these authors as indicating the youngest terrain at Storbreen. This suggests that a number of forelands at higher altitudes are characterised by species that tend to colonise at an earlier stage of succession than at lower altitudes where there may be greater separation of species within the pioneer stage as have defined here. $O$. digyna (subcommunity 2A) was found by Matthews (1978a) to be a late pioneer at Storbreen and was identified as common after 40 years by Whittaker (1993), who considered the possible control of its distribution by microsite variations in moisture availability. D. alpina was also found by Whittaker (1993) to attain peak abundance on 40-49-year-old terrain on the Storbreen foreland and to colonise older sites supplied with fresh glacial silt from meltwater. Other indicator species within sub-community $2 \mathrm{~A}$ include $O$. supina and $O$. norvegica, which are included in Matthews' (1978a) snowbed species group, and $P$. alpinum, which he considered to be a transitional species between the pioneer and the snowbed group. The $D$. alpina- $O$. digyna sub-community may therefore be characteristic of wetter sites, with laterlying snow. This is supported by Whittaker's (1991) directly measured shift in species composition over 12 years on Storbreen foreland from D. alpina and $O$. digyna to species characteristic of drier conditions (including T. spicatum).

Variance partitioning confirmed that altitude and continentality explain a significant percentage of the variation in species composition within this dataset. At a regional scale, therefore, climatic conditions attributable to altitude and degree of continentality would appear to be influencing pioneer assemblages. The component of continentality that is not correlated with altitude $(18 \%$ of total variance) suggests that seasonal extremes in temperature and precipitation may influence the early stages of glacier foreland colonisation (eastern sites being characterised by relatively cold, dry winters and hot, dry summers). At a local geographical scale, it is likely that habitat factors, such as snow distribution, microsite characteristics and stochasticity account for a high proportion of the unexplained variance.

\section{Conclusion}

The extensive, regional-scale sampling used in this project has led to results that support the concept of a degree of consistency in the species composition of pioneer plant communities on glacier forelands when examined at a broad (regional) scale. The overall level of variability between sites, demonstrated by a mean Sørensen dissimilarity of $65 \%$, is lower than that of pioneer species on disturbed roadside sites within the same altitudinal range. This arguably constitutes a poorly structured single community. However, when viewed at a finer scale, the pioneer vegetation appears to be more variable, with dominant species missing from several sites, suggesting a higher degree of stochasticity than in more mature communities.

As an alternative to forming a single community, the pioneer vegetation can be divided within a continuum of variation to produce two emerging sub-communities. These reflect the influence of environmental factors and, possibly, early successional development within the pioneer stage. Variance partitioning indicates, moreover, that altitudinal and continentality gradients are important in accounting for a significant proportion of the variability within this dataset. It would appear appropriate, therefore, to regard pioneer vegetation not as an entirely haphazard or random assortment 
of individual species but as an assemblage characterised by a low level of organisation (which becomes more organised later in succession).

Acknowledgements. Thanks to Robert Cook, Alexander Fuller, Geraint Owen and Paul Richards for fieldwork assistance, Anna Ratcliffe for producing the map, Roger del Moral and two anonymous referees for their useful comments and suggestions. The University of Wales and the Jotunheim Research Trust provided financial support This paper is Jotunheim Research Expeditions Contribution No. 168.

\section{References}

Aune, B. 1993. Temperatur normaler, normalperiode 19611990, Rapport 02/93. Den Norske Meteorologiske Instituut, Oslo.

Austin, M.P. 1999. A silent clash of paradigms: some inconsistencies in community ecology. Oikos 86: 170-178.

Austin, M.P. 2005. Vegetation and environment: discontinuities and continuities. In: van der Maarel, E. (ed.) Vegetation ecology. pp. 52-84. Blackwell Publishing, Oxford.

Bliss, L.C. 1971. Arctic and alpine plant life cycles. Annual Review of Ecology and Systematics 2: 405-438.

Bossuyt, B., Honnay, O. \& Hermy, M. 2003. An island biogeographical view of the successional pathway in wet dune slacks. Journal of Vegetation Science 14: 781-788.

Bray, J.R. \& Curtis, J.T. 1957. An ordination of the upland forest communities of southern Wisconsin. Ecological Monographs 27: 325-349.

Caccianiga, M., Andreis, C. \& Cerabolini, B. 2001 Vegetation and environmental factors during primary succession on glacier forelands: some outlines from the Italian Alps. Plant Biosystems 135: 295-310.

Chapin, F.S. III 1993. Physiological controls over plant establishment in primary succession. In: Miles, J. \& Walton, D.W.H. (eds.) Primary succession on land. pp. 161-178. Blackwell, Oxford.

Clarke, K.R. 1993. Non-parametric multivariate analyses of changes in community structure. Australian Journal of Ecology 18: 117-143.

Clements, F.E. 1916. Plant succession: an analysis of the development of vegetation. Carnegie Institute of Washington, Washington, DC.

Clements, F.E. 1936. Nature and structure of the climax. Journal of Ecology 24: 252-284.

Collins, S.L., Glenn, S.M. \& Roberts, D.W. 1993. The hierarchical continuum concept. Journal of Vegetation Science 4: 149-156.

Cottam, G. 1966. Vegetational continuum. Science 152: $546-547$.

Cutler, N.A., Belyea, L.R. \& Dugmore, A.J. 2008. The spatiotemporal dynamics of a primary succession. Journal of Ecology 96: 231-246.
Daubenmire, R. 1966. Vegetation: identification of typal communities. Science 151: 291-298.

del Moral, R. \& Jones, C. 2002. Vegetation development on pumice at Mount St. Helens, USA. Plant Ecology 162: 9-22.

del Moral, R., Wood, D.M. \& Titus, J.H. 2005. Proximity, microsites, and biotic interactions during early succession. In: Dale, V.H., Swanson, F.J. \& Crisafulli, C.M. (eds.) Ecological responses to the 1980 eruption of Mount St. Helens. pp. 93-109. Springer, New York, US.

Dufrene, M. \& Legendre, P. 1997. Species assemblages and indicator species: the need for a flexible asymmetrical approach. Ecological Monographs 61: 345-366.

Ellenberg, H. 1974. Zeigerwerte von Gefasspflanzen Mitteleuropas. Scripta Geobotanica 9: 97-219.

Elven, R. 1978. Vegetasjonen ved Flatisen og Osterdalsisen, Rana, Nordland, med vegetationskart over Vesterdalen i 1:5,000. In: Museet Rapport, Botanisk Serie. pp. 1-83. Norske Videnskabers Selskab, Trondheim, Norway.

Faith, D.P., Minchin, P.R. \& Belbin, L. 1987. Compositional dissimilarity as a robust measure of ecological distance. Vegetatio 69: 57-68.

Førland, E.J. 1993. Nedbornnormaler normalperiode 196190, Rapport 39/93. Den Norske Meteorologiske Institutt, Oslo.

Foster, B.L. \& Tilman, D. 2000. Dynamic and static views of succession: testing the descriptive power of the chronosequence approach. Plant Ecology 146: 1-10.

Gleason, H.A. 1917. The structure and development of the plant association. Bulletin of the Torrey Botanical Club 44: 463-481.

Gleason, H.A. 1927. Further views on the succession concept. Ecology 8: 299-236.

Grime, J.P. 1979. Plant strategies and vegetation processes. Wiley \& Sons, Chichester.

Haugland, J.E. \& Beatty, S.W. 2005. Vegetation establishment, succession and microsite frost disturbance on glacier forelands within patterned ground chronosequences. Journal of Biogeography 32: 145-153.

Isaksen, K., Hauck, C., Gudevang, E., Odegard, R.S. \& Sollid, J.L. 2002. Mountain permafrost distribution in Dovrefjell and Jotunheimen, southern Norway, based on BTS and DC resistivity tomography data. Norsk Geografisk Tidsskrift 56: 122-136.

Jones, C.C. \& del Moral, R. 2005. Patterns of primary succession on the foreland of Coleman Glacier, Washington, USA. Plant Ecology 180: 105-116.

Jumpponen, A., Vare, H., Mattson, K.G., Ohtonen, R. \& Trappe, J.M. 1999. Characterization of 'safe sites' for pioneers in primary succession on recently deglaciated terrain. Journal of Ecology 87: 98-105.

Kruskal, J.B. \& Wish, M. 1978. Multidimensional scaling. Sage Publications, Beverley Hills.

Lepš, J. \& Š Śmilauer, P. 2003. Multivariate analysis of ecological data using CANOCO. Cambridge University Press, Cambridge, UK. 
Lid, J. \& Lid, D.T. 1994. Norsk flora. Det Norske Samlaget, Oslo.

Lortie, C.J., Brooker, R.W., Choler, P., Kikvidze, Z., Michalet, R., Pugnaire, F.I. \& Callaway, R.M. 2004. Rethinking plant community theory. Oikos 107: 433438.

Mather, P.M. 1976. Computational methods of multivariate analysis in physical geography. John Wiley, London.

Matthews, J.A. 1978a. An application of non-metric multidimensional scaling to the construction of an improved species plexus. Journal of Ecology 66: 157-173.

Matthews, J.A. 1978b. Plant colonization patterns on a Gletschervorfeld, southern Norway: a meso-scale geographical approach to vegetation change and phytometric dating. Boreas 7: 155-178.

Matthews, J.A. 1979a. Refutation of convergence in a vegetation succession. Naturwissenschaften 66: 47-49.

Matthews, J.A. 1979b. A study of the variability of some successional and climax plant assemblage-types using multiple discriminant analysis. Journal of Ecology 67: 255-271.

Matthews, J.A. 1979c. Vegetation of the Storbreen Gletschervorfeld, Jotunheimen, Norway - introduction and approaches involving classification. Journal of Biogeography 6: 17-47.

Matthews, J.A. 1979d. Vegetation of the Storbreen Gletschervorfeld, Jotunheimen, Norway. 2. Approaches involving ordination and general conclusions. Journal of Biogeography 6: 133-167.

Matthews, J.A. 1992. The ecology of recentlydeglaciated terrain. CUP, Cambridge, UK.

Matthews, J.A. 1999. Disturbance regimes and ecosystem response on recently-deglaciated substrates. In: Walker, L.R. (ed.) Ecosystems of disturbed ground. pp. 17-37. Elsevier, Amsterdam.

Matthews, J.A. \& Whittaker, R.J. 1987. Vegetation succession on the Storbreen glacier foreland, Jotunheimen, Norway - a review. Arctic and Alpine Research 19: 385-395.

McCook, L.J. 1994. Understanding ecological community succession: causal models and theories, a review. Vegetatio 110: 115-147.

McCune, B. \& Grace, J.B. 2002. Analysis of ecological communities. MjM Software Design, Gleneden Beach, OR.

McCune, B. \& Mefford, M.J. 1999. PC-ORD. Multivariate analysis of ecological data. Version 4.33. MjM Software, Gleneden Beach, OR.

Mielke, P.W.J. \& Berry, K.J. 2001. Permutation methods: a distance function approach. Springer, New York.

Moreau, M., Mercier, D., Laffly, D. \& Roussel, E. 2008. Impacts of recent paraglacial dynamics on plant colonization: a case study on Midtre Lovenbreen foreland, Spitsbergen (79N). Geomorphology 95: 4860 .

Mori, A.S., Osono, T., Uchida, M. \& Kanda, H. 2008. Changes in the structure and heterogeneity of vegetation and microsite environments with the chronosequence of primary succession on a glacier foreland in Ellesmere Island, high arctic Canada. Ecological Research 23: 363-370.

Nesje, A. 1989. Glacier-front variations of the outlet glaciers from Jostedalsbreen and climate in the Jostedalsbre region of western Norway in the period 1901-1980. Norsk Geografisk Tidsskrift 43: 3-17.

Nesje, A., Bakke, J., Dahl, S.O., Lie, O. \& Matthews, J.A. 2008. Norwegian mountain glaciers in the past, present and future. Global and Planetary Change 60: $10-28$.

Økland, R.H. \& Eilertsen, O. 1994. Canonical correspondence analysis with variation partitioning: some comments and an application. Journal of Vegetation Science 5: 117-126.

Oksanen, J. \& Minchin, P.R. 2002. Continuum theory revisited: what shape are species responses along ecological gradients? Ecological Modelling 157: 119-129.

Peat, H. \& Fitter, A. 2007. Ecological flora of the British Isles. Available at http://www.york.ac.uk/res/ecoflora/ cfm/ecofl/. Accessed 2 April 2007.

Persson, A. 1964. The vegetation at the margin of the receding glacier Skaftafellsjokull, southeastern Iceland. Botaniska Notiser 117: 323-354.

Pickett, S.T.A. \& Cadenasso, M.L. 2005. Vegetation dynamics. In: van der Maarel, E. (ed.) Vegetation ecology. pp. 172-198. Blackwell Publishing, Oxford.

Post, W.M. \& Sheperd, J.D. 1974. Hierarchical agglomeration. University of Wisconsin, Madison.

Raffl, C., Mallaun, M., Mayer, R. \& Erschbamer, B. 2006. Vegetation succession pattern and diversity changes in a glacier valley, Central Alps, Austria. Arctic, Antarctic and Alpine Research 38: 421-428.

Robbins, J.A. 2007. The pioneer plant community: studies on roadside verges, glacier forelands and other disturbed habitats in southern Norway. Ph.D. thesis, Swansea University, 389pp.

Ryvarden, L. 1971. Studies of seed dispersal I. Trapping of diaspores in the alpine zone at Finse, Norway. Norwegian Journal of Botany 18: 215-226.

Spence, J.R. 1989. Plant succession on glacial deposits of Mount Kenya, East Africa. In: Mahaney, W.C. (ed.) Quaternary and environmental research on East African mountains. pp. 279 -290. Balkema, Rotterdam.

Stöcklin, J. \& Bäumler, E. 1996. Seed rain, seedling establishment and clonal growth strategies on a glacier foreland. Journal of Vegetation Science 7: 45-56.

ter Braak, C.J.F. \& Šmilauer, P. 2006. Canoco for windows version 4.54. Biometris - Plant Research International, Wageningen.

Vetaas, O.R. 1994. Primary succession of plant assemblages on a glacier foreland - $\mathbf{B} \varnothing$ dalsbreen, southern Norway. Journal of Biogeography 21: 297-308.

Vetaas, O.R. 1997. Relationships between floristic gradients in a primary succession. Journal of Vegetation Science 8: 665-676. 
Walker, L.R. \& del Moral, R. 2003. Primary succession and ecosystem rehabilitation. CUP, Cambridge, UK.

Whittaker, R.H. 1951. A criticism of the plant association and climatic climax concepts. Northwest Science 25: 7-31.

Whittaker, R.H. 1967. Gradient analysis of vegetation. Biological Review 49: 207-264.

Whittaker, R.J. 1989. The vegetation of the Storbreen Gletschervorfeld, Jotunheimen, Norway .3. Vegetation environment relationships. Journal of Biogeography 16: 413-433.

Whittaker, R.J. 1991. The vegetation of the Storbreen Gletschervorfeld, Jotunheimen, Norway. IV. Shortterm vegetation change. Journal of Biogeography 18: $41-52$.
Whittaker, R.J. 1993. Plant population patterns in a glacier foreland succession: pioneer herbs and latercolonizing shrubs. Ecography 16: 117-136.

Winkler, S. 1996. Front variations of outlet glaciers from Jostedalsbreen, Western Norway, during the twentieth century. Norges Geologisk Undersøkelse Bulletin 431: 33-47.

Wishart, D. 1969. An algorithm or hierarchical classifications. Biometrics 25: 165-170.

Received 10 November 2008; Accepted 29 April 2009. Coordinating editor: $\mathrm{H}$. Bruelheide. 